\title{
Chinese herbs and their active ingredients for activating xue (blood) promote the proliferation and differentiation of neural stem cells and mesenchymal stem cells
}

Yin-chu Si ${ }^{1^{*}}$, Qiang Li $i^{2}$, Chun-e Xie ${ }^{3}$ Xin Niu ${ }^{4}$, Xiao-hui Xia ${ }^{5}$ and Chang-yuan Yu ${ }^{6}$

\begin{abstract}
Some Chinese herbs are anti-thrombolysis, and anti-inflammatory, improves brain RNA content, promotes brain protein synthesis, enhances dopamine function, regulates brain hormones, and improves microcirculation in central nervous system that might improve, repair and rehabilitation from the stroke and brain injury. Specific Chinese herbs and their components, such as Acanthopanax, Angelica, could maintain the survival of neural stem cells, and Rhodiola, Ganoderma spore Polygala, Tetramethylpyrazine, Gardenia, Astragaloside and Ginsenoside Rg1 promoted proliferation of neural stem cells, and Rhodiola, Astragaloside promoted differentiation of neural stem cell into neuron and glia in vivo. Astragalus, Safflower, Musk, Baicalin, Geniposide, Ginkgolide B, Cili polysaccharide, Salidroside, Astragaloside, Antler polypeptides, Ginsenoside Rg1, Panax notoginseng saponins promoted proliferation and differentiation of neural stem cells in vitro. Salvia, Astragalus, Ginsenoside Rg1, P. notoginseng saponins, Musk polypeptide, Muscone and Ginkgolide B promoted neural-directed differentiation of MSCs into nerve cells. These findings are encouraging further research into the Chinese herbs for developing drugs in treating patients of stroke and brain injury.
\end{abstract}

\section{Introduction}

Neural stem cells (NSC) in the central nervous system are capable of self-replication, proliferation, migration and differentiation [1]. They can be differentiated into the essential cells for the brain and spinal cord tissue, including neurons, astrocytes and oligodendrocytes [2]. This discovery contravened the dogma [3] that new neurons involving in the repair of nerve tissue cannot be produced after neuronal degeneration and necrosis in the central nervous system (CNS). Therapy using NSC technology has emerged as a viable alternative treatment for neural injury [4].

There are two intervention strategies involving NSCs in the treatment of CNS injury and degenerative diseases. The first strategy involves endogenous NSCs to repair the lesion sites [5], but it is an issue that the proliferation of

\footnotetext{
* Correspondence: siyc@bucm.edu.cn

'Department of Anatomy, Beijing University of Chinese Medicine, Chaoyang District, Beijing 100029, China

Full list of author information is available at the end of the article
}

endogenous NSCs is insufficient [6]. Methods including chemotherapy, stimulation of endogenous NSC proliferation, and induced directional migration and differentiation are under research [7]. The second strategy involves the exogenous transplantation of NSCs into the lesion sites [8]. Transplanted NSCs must survive, replicate, and differentiate into local nerve cells, for repairing the injury [9]. The requirements of precursor cells or nerve cells for directional induction at the lesion sites have been under research. The efficacy of Chinese medicine $(\mathrm{CM})$ in the prevention and treatment of diseases of the central nervous system has been a major research issue for decades in the neuroscience and medicine [10].

After screening a number of Chinese herbs and their active ingredients in vitro and in vivo, CM was demonstrated to have various effects on NSCs in many aspects [11]. This study aims to focus on the efficacy and roles of CM in the survival, self-proliferation, directed migration, and differentiation of NSCs. 


\section{Methods for studying proliferation and directed differentiation of neural stem cells in vivo}

Endogenous NSCs are restricted to two main regions: subgranular zone (SGZ) of the hippocampal dentate gyrus (DG) and the subventricular zones (SVZ) of the lateral ventricles in adults $[12,13]$. Cells in the SVZ proliferate and form the rostral migratory stream to the olfactory bulb, and then differentiate into granular cells [14]. Cells in the SGZ proliferate and migrate to the granular cell layer, and then differentiate into new granule cells [15]. There are also self-replicating NSCs in other parts of brain, such as the cortex and striatum, which can differentiate into cerebral nerve cells [16]. In the case of injury activated, NSCs proliferate and migrate to the sites of injury, differentiate into new nerve cells, replace damaged nerve cells, participate in the formation of new neural circuits, and promote structural and functional repair $[17,18]$.

The number of neural cells induced by brain damage stimulation on SVZ NSC proliferation is too limited to repair the injury [6]. Some Chinese herbs (e.g., Panax ginseng, Panax notoginseng) improve rehabilitation from brain injury and degenerative diseases [10]. The Chinese herbs and their active ingredients (e.g., ginsenosides) provide a promote the proliferation and differentiation of NSCs [19].

\section{Animal models and screening methods in vivo}

Rodent models of transient global cerebral ischemia, hypotonic hypoxia (which causes embryonic, intrauterine hypoxia), spinal cord injury, cerebral ischemia, chronic stress, Alzheimer's disease (AD), middle cerebral artery occlusion, cerebral ischemia, and cerebral hemorrhage are available for screening Chinese herbs [20]. For oral administration, a single herb decoction (e.g., Acanthopanax, Rhodiola.) was usually employed. For intravenous and intraperitoneal injections, active components (e.g., Astragaloside ginsenosides $\operatorname{Rg} 1$ ) of Chinese herbs were often used. The numbers of nestin- and BrdU-positive cells in Chinese herb treatment groups (Acanthopanax, Rhodiola and Astragaloside ginsenosides Rg1) were statistically different from the control groups $(P<0.05$ or 0.01$)$ in stroke rat brain $[20,21]$, indicating significant effects of the treatments on the self-replication and proliferation of NSCs. The numbers of cells double-positive for $\beta$-tubulin III/BrdU, olig2/BrdU and GFAP/BrdU were also changed by the treatment with Chinese herbs and their components, indicating their effect on the differentiation of NSCs [21]. The effects of Chinese medicines and active ingredients on the proliferation and differentiation of NSCs in the SVZ, SGZ, cortex, hippocampus, striatum, and foci of ischemia, hemorrhage, have been investigated as described in the following sections.

\section{Effects on proliferation and differentiation in vivo}

Table 1 summarizes the effect of Chinese herbs on differentiation of NSCs in vivo. Acanthopanax (Ciwujia) consists of dried roots and rhizomes or stems of Araliaceae Acanthopanax [22]. Ciwujia increased nestin-positive cell number in Sprague-Dawley rats with cerebral ischemic lesions 5-7 days after transient global cerebral ischemia with rat tail vein injection. These findings were consistent with the improvement of neurological functions [23]. Angelica (Danggui) is the dried roots of Angelica Umbelliferae [24], which increased the number of nestin-positive cells in intrauterine hypoxia brain after angelica injection $(250 \mathrm{~g} / \mathrm{L}$ Angelica injection, $8 \mathrm{~mL} / \mathrm{kg}$ body weight) [25]. Rhodiola (Hongjingtian) is the dried roots or rhizomes of sedum Rhodiola crenulata [26]. Hongingtian decoction $(1.5 \mathrm{~g} / \mathrm{kg})$ increased the percentages of BrdU-labeled cells and BrdU/ $\beta$-tubulin III double-labeled cells in the SGZ of the hippocampal dentate gyrus after for 12 days of Oral administration to depressive rats [27]. Rhodiola rosea (15 mg/kg) increased the number of BrdU-positive cells, the percentages of BrdU- and $\beta$-tubulin III double-labeled cells and the numbers of neurons in the hippocampus of depressive rats [27]. Ganoderma (lingzhi) is the dried fruiting bodies of the Polyporaceae fungus Ganoderma lucidum [26]. Ganoderma spore solution (8 g/kg/d) increased BrdU-positive staining quantity in central canal ependymal cells of the rat spinal cord after gastric feeding (2 mL) twice a day after T12 spinal cord injury [28]. Some BrdU-positive cells in the spinal cord white matter simultaneously expressed oligedendroyte-specific proteins, nestin, neurofilament proteins (NF) or glial fibrillary acidic protein (GFAP). Polygala (Yuanzhi) is the dried roots of Polygalaceae [29], and increased the numbers of BrdUpositive cells in the DG of the hippocampus in the AD mouse [30]. The numbers of BrdU-positive cells in the DG were positively correlated with spatial memory scores in each group of mice with different doses of Polygala (r = 0.624; $P<0$ 01).

Intraperitoneal injection of tetramethylpyrazine [40 mg/ $(\mathrm{kg} \bullet \mathrm{d})]$ one day after cerebral ischemia promoted BrdU expression in the SGZ. The effect peaked after 7 days, and remained observable for 21 days. The Astragaloside ginsenoside $\operatorname{Rg} 1$ increased the numbers of BrdU-positive cells and BrdU/GFAP double-positive cells in the rat CA1 hippocampal DG region in a transient brain ischemia model [32]. A reverse-transcription polymerase chain reaction analysis showed that astragaloside upregulated nerve growth factor (NGF) mRNA expression after 7 days. The astragaloside promoted the proliferation of NSCs in the hippocampus, and induced them to differentiate into astrocytes, which might be related to the increase in NGF mRNA expression [34,35]. Rg1 and P. notoginseng saponins promoted nestin and BrdU immune responses in the hippocampal DG, the subventricular zone, the CA1 region 


\begin{tabular}{|c|c|c|c|c|}
\hline $\begin{array}{l}\text { Chinese herbs and } \\
\text { active ingredients }\end{array}$ & Animal model & Sites of neural stem cells & $\begin{array}{l}\text { The role of } \\
\text { proliferation }\end{array}$ & $\begin{array}{l}\text { The role of } \\
\text { differntiation }\end{array}$ \\
\hline $\begin{array}{l}\text { Acanthopanax } \\
{[22,23]}\end{array}$ & $\begin{array}{l}\text { Transient global cerebral } \\
\text { ischemia in rats }\end{array}$ & $\begin{array}{l}\text { Hippocampus, ependymal, } \\
\text { subependymal region, ischemic area }\end{array}$ & Nestin positive cells $\uparrow$ & \\
\hline Angelica $[24,25]$ & $\begin{array}{l}\text { The intrauterine hypoxia } \\
\text { embryonic rats }\end{array}$ & Whole brain & Nestin positive cells $\uparrow$ & \\
\hline Rhodiola $[26,27]$ & Chronic stress rats & Hippocampus & BrdU positive cells $\uparrow$ & $\begin{array}{l}\text { BrdU/ } \beta \text {-tubulin } \uparrow . \text { Neuronal } \\
\text { directed differentiation }\end{array}$ \\
\hline $\begin{array}{l}\text { Ganoderma spore } \\
{[26,28]}\end{array}$ & Spinal cord injury in rats & Central canal ependymal zone & BrdU positive cells $\uparrow$ & $\begin{array}{l}\text { BrdU/NF; BrdU/GFAP; } \\
\text { BrdU/Oligo } \uparrow\end{array}$ \\
\hline Polygala $[29,31]$ & $\begin{array}{l}\text { Mouse AD model (D-galactose + } \\
\text { sodium nitrite intraperitoneal } \\
\text { injection) }\end{array}$ & SGZ & BrdU positive cells $\uparrow$ & \\
\hline $\begin{array}{l}\text { Tetramethylpyrazine } \\
\text { [32] }\end{array}$ & $\begin{array}{l}\text { Ischemia-reperfusion of cerebral } \\
\text { ischemia in rats }\end{array}$ & SGZ & BrdU positive cells $\uparrow$ & \\
\hline Gardenia [33] & Chronically stressed mice & SGZ & BrdU positive cells $\uparrow$ & \\
\hline $\begin{array}{l}\text { Astragaloside } \\
{[32,34,35]}\end{array}$ & $\begin{array}{l}\text { Transient forebrain ischemia in } \\
\text { rats }\end{array}$ & CA1 of hippocampus, SGZ & BrdU positive cells $\uparrow$ & BrdU/MAP-2; BrdU/GFAP; $\uparrow$ \\
\hline $\begin{array}{l}\text { Ginsenoside Rg1 } \\
{[19,32,36-40]}\end{array}$ & MCAO rats & SVZ, SGZ, CA1 of hippocampus & $\begin{array}{l}\text { Nestin, BrdU and } \\
\text { nestin/BrdU positive } \\
\text { cells } \uparrow\end{array}$ & \\
\hline \multirow{2}{*}{$\begin{array}{l}\text { Panax notoginseng } \\
\text { saponins [19,36-39] }\end{array}$} & MCAO rats & SVZ, Hippocampus and cortex & Nestin positive cells $\uparrow$ & Nestin/GFAP $\uparrow$ \\
\hline & Cortical devascularization rats & SVZ & Nestin positive cells $\uparrow$ & \\
\hline
\end{tabular}

of the hippocampus, and the cortex (including the area showing ischemic involvement in MCAO rats), and peaked 7 days after ischemia [19,36-39]. Activation of NMDA receptors was involved in the effect of $\operatorname{Rg} 1$ on hippocampal precursor cells [40]. Rg1 increased the number of nestin-positive cells in the rats brains with cerebral hemorrhage, and improved their motor function [30]. Gardenia crude extract elevated the numbers of NeuNpositive neurons in the hippocampal DG after 8 weeks of treatment, and increased the surface density of BrdUpositive cells [33]. Gardenia crude extracts improved cognitive function in depression model mice, and promoted neurogenesis in the hippocampus, suggesting an antidepressant effect of the gardenia crude extract (Table 1).

\section{Effects on the proliferation and directed differentiation of NSCs in vitro}

NSCs can be isolated, cultured, purified and identified from the cerebral cortex, hippocampus, striatum, and SVZ of embryonic and neonatal rats [2]. There were morphological changes of and monoclonal cell sphere formation by neural stem cells after induction with Chinese herbs and its effective active ingredients [39]. The numbers of nestin- and BrdU-positive cells were assessible by radioisotope labeling and immunohistochemistry. The numbers of immune double labeling positive cells of B-tubulin III/ BrdU, MAP-2/BrdU, olig2/BrdU and GFAP/BrdU and flow cytometry may show the role of Chinese herbs and its components in directed differentiation.

Table 2 summarizes the roles of Chinese herbs in NSC differentiations in vitro. Astragalus (Huang Qi) injection $(30 \mu \mathrm{L} / \mathrm{mL})$ promoted the differentiation of NSCs into neurons in the E13 embryo rat $[41,42]$. An aqueous solution of musk (She Xiang) dispersed clusters of rat NSCs, increasing the numbers and lengths of neurites. An aqueous solution of musk $(0.3 \%)$ promoted NSCs to differentiate into glial-like cells, while a higher concentration (3\%) caused cytotoxicity [43].

Baicalin promoted the survival of NSCs in embryonic rats with an increase of $42.3 \%$ determined by MTT assay [44]. Salidroside serum significantly promoted hippocampal NSCs to differentiate into neurons in a dose-dependent manner [34]. Different concentrations of ginkgolide $B$ (20, 40, and $60 \mathrm{mg} / \mathrm{L})$ added to DMEM/F12 medium promoted NSC differentiation into neuron-like cells when they were cultured for 7 or 14 days [34]. The relationship between differentiation and concentration was not significant, and the concentration had little effect on the percentage of oligodendrocytes. However, the percentage of astrocyte-like cells increased with the concentration of ginkgolide $B[46,47]$. Different concentrations of rose roxburghii tratt polysaccharide (RRTP) (20, 40, and $80 \mu \mathrm{mol} / \mathrm{L})$ reduced the degree of injury of embryonic rat striatal neural stem cells caused by glutamate. A high concentration of RRTP $(60 \mathrm{mg} / \mathrm{L})$ significantly reduced 
Table 2 The role of Chinese herbs and its active ingredients on proliferation and differentiation of neural stem cells in vitro

\begin{tabular}{|c|c|c|c|c|}
\hline $\begin{array}{l}\text { Chinese herbs and } \\
\text { active ingradients }\end{array}$ & Types of neural stem cells & $\begin{array}{l}\text { The role of } \\
\text { proliferation }\end{array}$ & The role of differentiation & Mechanism \\
\hline Astragalus $[41,42]$ & $\begin{array}{l}14 d \text { cortical NSCs of } \\
\text { embryonic rats }\end{array}$ & & NF and GFAP positive cells $\uparrow$ & \\
\hline Musk [43] & $\begin{array}{l}14 d \text { striatal NSCs of } \\
\text { embryonic rats }\end{array}$ & & $\begin{array}{l}\text { Electrotransfer rate of pEGFP- } \\
\text { C1 } 1 \text { Glial-like cell directed } \\
\text { differentiation }\end{array}$ & \\
\hline Baicalin [44] & $\begin{array}{l}\text { Cortical NSCs of embryonic } \\
\text { rats }\end{array}$ & & $\begin{array}{l}\beta \text {-tubulin and MAP-2 positive } \\
\text { cells } \uparrow \uparrow\end{array}$ & \\
\hline Geniposide [19] & $\begin{array}{l}\text { Cortical NSCs of embryonic } \\
\text { rats }\end{array}$ & & $\beta$-tubulin positive cells $\uparrow$ & \\
\hline $\begin{array}{l}\text { Baicalin + astragaloside, [45] } \\
\text { Baicalin + P. notoginseng } \\
\text { saponins [38] }\end{array}$ & $\begin{array}{l}\text { Cortical NSCs of embryonic } \\
\text { rats }\end{array}$ & & $\begin{array}{l}\text { Expression of Tau个 (adults } \\
\text { neurons) }\end{array}$ & \\
\hline \multirow[t]{3}{*}{ Ginkgolide B $[34,46,47]$} & $\begin{array}{l}\text { Hippocampal NSCs of } \\
\text { Neonatal rat, E14 SVZ NSCs of } \\
\text { embryonic rats }\end{array}$ & & $\begin{array}{l}\text { NF cells (Has nothing to do } \\
\text { with the concentration) } \uparrow \text {, } \\
\text { GFAP cells (Positively correlated } \\
\text { with the concentration) } \uparrow\end{array}$ & \\
\hline & SVZ NSCs of adult rats & & MAP-2 cells $\uparrow$ & \\
\hline & SVZ NSCs of neonatal mice & & $\beta$-tubulin and GFAP cells $\uparrow$ & \\
\hline Cili polysaccharide [48] & $\begin{array}{l}\text { 14d embryonic rat striatal } \\
\text { NSCs (glutamic acid damage) }\end{array}$ & & & $\begin{array}{l}\text { Protection. Cell death rate } \downarrow \text {; } \\
\text { lactate dehydrogenase } \\
\text { leakage rate } \downarrow\end{array}$ \\
\hline Salidroside [34] & $\begin{array}{l}\text { Hippocampal NSCs of } \\
\text { neonatal rats }\end{array}$ & & NSE cells $\uparrow$ & \\
\hline \multirow{3}{*}{$\begin{array}{l}\text { Quercetin-3-O-celery } \\
\text { glucoside (CTN-986) [49] }\end{array}$} & \multirow{2}{*}{$\begin{array}{l}\text { Hippocampal NSCs of } \\
\text { neonatal rats }\end{array}$} & $\mathrm{MTT} \uparrow$ & & \\
\hline & & $3 \mathrm{H}-\mathrm{TdR}$ intake $\uparrow$ & & \\
\hline & $\begin{array}{l}14 d \text { cortical NSCs of } \\
\text { embryonic rats }\end{array}$ & $\mathrm{NSCs} \uparrow$ & & $\begin{array}{l}\text { The expression of Hes5 } \\
\text { and Cyclin D1 }\end{array}$ \\
\hline Antler polypeptides [50] & $\begin{array}{l}14 d \text { cortical NSCs of } \\
\text { embryonic rats }\end{array}$ & & NSE cells $\uparrow$ & \\
\hline $\begin{array}{l}\text { Ginsenoside Rg1 } \\
{[21,40,51,52]}\end{array}$ & $\begin{array}{l}14 \mathrm{~d} \text { cortical NSCs of } \\
\text { embryonic rats }\end{array}$ & BrdU cells $\uparrow$ & & $\begin{array}{l}\text { The expression of Hes } 1 \\
\text { and Mash1 } \uparrow\end{array}$ \\
\hline TSPG [53] & Human embryonic NSCs & $\mathrm{MTT} \uparrow$ & $\begin{array}{l}\text { Directed differentiation of DA } \\
\text { neuron }\end{array}$ & \\
\hline $\begin{array}{l}\text { P. notoginseng saponins } \\
{[39,54]}\end{array}$ & $\begin{array}{l}\text { E17 cortical and hippocampal } \\
\text { NSCs of neonatal rats }\end{array}$ & $\begin{array}{l}\text { Nestin and PCNA } \\
\text { cells } \uparrow\end{array}$ & $\begin{array}{l}\text { Tuj1, NF, vimentin and GFAP } \\
\text { cells } \uparrow\end{array}$ & $\begin{array}{l}\text { The expression of BDNF } \\
\text { and bFGF }\end{array}$ \\
\hline
\end{tabular}

mortality and the rate of leakage of lactate dehydrogenase from NSCs, suggesting a protective effect of RRTP against NSC damage [48]. Quercetin-3-O-celery glucoside had a distinct effect on the survival and proliferation of neonatal rat hippocampus neural precursor cells with MTT and DNA synthesis of isotopically labeled precursors 3H-TdR detection [49]. Astragalus saponin induced the differentiation of NSCs in the SVZ and cortex in embryonic mouse brains into neurons. This induction showed no concentration effect $[55,56]$.

Brain microvascular endothelial cells, astrocytes and NSCs were co-cultured for 7 days with baicalin [45]. While baicalin increased the proportions of $\beta$-tubulin III-positive cell when NSCs were co-cultured with brain microvascular endothelial cells; however, it had no significant effect on the proportions of $\beta$-tubulin III-, MAP-2- and glial fibrillary acidic protein-positive cells when NSCs were co-cultured with astrocytes. When brain microvascular endothelial cells and astrocytes were co-cultured in baicalin medium, the proportion of MAP-2-positive cells was increased [45]. Baicalin increased the level of gene expression for plateletderived growth factor in brain microvascular endothelial cells after culture for $48 \mathrm{~h}$ [45]. After $72 \mathrm{~h}$ of culture, baicalin raised the level of gene expression for vascular endothelial growth factor, nerve growth factor and platelet-derived growth factor in astrocytes. Baicalin induced the differentiation of NSCs into neurons when the stem cells were co-cultured with brain microvascular endothelial cells [45]. It also induced directed differentiation of NSCs into neurons when stem cells were co- 
cultured with brain microvascular endothelial cells and astrocytes. The effect of baicalin was related to the regulation of growth factor secretion from brain microvascular endothelial cells and astrocytes, and an improved microenvironment (Table 2) [45].

After the culture of embryonic rat brain cortex neural stem cells in different concentrations of antler polypeptides medium for $24 \mathrm{~h}$, the resultant neurospheres produced many cells with extended protrusions, as well as numerous differentiated cells on the $7^{\text {th }}$ day [50]. Some cells with visible split-shaped nuclei were detected; some of these cells extended dendritic processes and formed a network. The difference in the levels of neuron-specific enolase (NSE) immunohistochemistry between cells cultured with antler polypeptides and the control group showed that the antler polypeptides promoted NSCs differentiation into neurons and suggested a potential treatment of nervous system diseases with velvet antler polypeptide.

Rg1 had effects on the proliferation of hippocampal neural precursor cells in vitro as shown by increased 3 $[\mathrm{H}]$-thymidine incorporation and colony formation rates [40]. Rg1 increased the number of BrdU-positive cells among rat fetal mouse NSCs, and upregulated Hes1 gene expression [51]. Rg1 promoted proliferation of embryonic rat SVZ NSCs and protected them against glutamateinduced damage, and this effect was relevant for increasing the percentage of STAT3-positive cells [21,52].

The ginsenoside saponins promoted the proliferation of human embryonic NSCs [54]. When ginsenoside saponins were combined with EGF and bFGF, the effect of proliferation was two times more potent than the combination of just EGF or bFGF. Ginsenoside saponins promoted directed differentiation of NSCs into dopaminergic neurons
[53]. When ginsenoside saponins were combined with IL-1, the effect on proliferation was five times more potent than that induced by IL-1 alone [57]. Tanshinone (20, 40, and $80 \mu \mathrm{mol} / \mathrm{L}$ ) exhibited a protective effect on rat NSCs affected by hypoxia and oxidants in vitro [57] (Table 2). Tanshinone had a greater protective effect on hypoxia damage than on oxidant damage at the same dose.

\section{Effects on the outcomes following transplantation of NSCs}

Rat models of acute spinal cord injury (ASCI) were established by Allen's method [58]. NSCs transfected with neurotrophin-3 (NT-3) were transplanted into the spinal cords of model rats [59]. Model rats were arbitrarily allocated into a model control (group A), a transplantation of NSCs transfected with NT-3 mediated by adenovirus group (group B), a NSC transplantation plus ginkgo biloba leaf extract group (group C), and a ginkgo biloba leaf extract group (group D). Two weeks after transplantation, the cortical somatosensory-evoked potential disappeared in groups $\mathrm{B}$ and $\mathrm{C}$. Eight weeks after transplantation, the waveforms in groups $\mathrm{B}$ and $\mathrm{C}$ were restored to normal, but the latency was extended. At the same time, more NSCs expressing NT-3 were observed in the ependyma of the spinal cord. Six weeks later, nerve fiber bundles were seen in the lesion area, and there were more nerve fiber bundles in groups $\mathrm{B}$ and $\mathrm{C}$ than in groups $\mathrm{A}, \mathrm{D}$. Therapy with ginkgo biloba leaf extract combined with transplantation of nerve stem cells transfected with NT-3 promoted the repair or regeneration of neurons, improved conduction function, and increased the numbers of nerve fiber bundles in the injured spinal cord following acute spinal cord injury.

Table 3 The role of Chinese herbs and its active ingredients to promote bone marrow mesenchymal stem cells differentiate into nerve cells

\begin{tabular}{|c|c|c|c|c|}
\hline $\begin{array}{l}\text { Chinese herbs and active } \\
\text { ingraients }\end{array}$ & Types of MSCs & $\begin{array}{l}\text { The role of } \\
\text { proliferation }\end{array}$ & The role of differentiation & Mechanism \\
\hline \multirow[t]{3}{*}{ Salvia [62-64] } & MSCs of mouse & Nestin cells $\uparrow$ & $\beta$-tubulin cells $\uparrow$ & \\
\hline & MSCs of rat & Nestin cells $\uparrow$ & NSE cells $\uparrow$ & $\begin{array}{l}\text { Expression of } \\
\text { Ngn-1 and } \\
\text { Mash-1 } \uparrow\end{array}$ \\
\hline & MSCs of human & Nestin cells $\uparrow$ & NF cells $\uparrow$ & \\
\hline Astragalus [65] & MSCs of rat & & NSE cells $\uparrow$ & $\begin{array}{l}\text { Expression of } \\
\text { Ngn-1 and } \\
\text { Mash-1 } \uparrow\end{array}$ \\
\hline Ginsenoside Rg1 $[66,67]$ & MSCs of rat & & NSE cells $\uparrow$ & $\begin{array}{l}\text { Expression of } \\
\text { NGFmRNA } \uparrow\end{array}$ \\
\hline $\begin{array}{l}\text { P. notoginseng saponins + } \\
\text { retinoic acid [33-37] }\end{array}$ & MSCs of rat & & NSE cells $\uparrow$ DA, GABA cells & \\
\hline $\begin{array}{l}\text { Musk polypeptide, } \\
\text { Muscone [43] }\end{array}$ & MSCs of rat & & T NSE and NF cells $\uparrow$ & \\
\hline Ginkgolide B [47,60,61] & MSCs of rat & & $\begin{array}{l}\text { NSE cells } \uparrow \text { (Has nothing to do with the concentration). The number } \\
\text { of GFAP cells GFAP } \uparrow \text { (Positively correlated with the concentration). }\end{array}$ & \\
\hline
\end{tabular}




\section{Effects on the differentiation of mesenchymal stem cells into nerve cells}

Table 3 summarizes the role of Chinese herbs and its active ingredients in differentiating bone marrow mesenchymal stem cells (MSCs) into nerve cells. Ginkgolide B induced the directed differentiation of MSCs in rats [60]. The percentages of NSE-positive neuron-like cells in the different concentrations of ginkgolide B were higher than the percentage in the control group. However, there were no significant differences between the different concentrations. The proportion of GFAP-positive astrocyte-like cells in the different concentrations of ginkgolide $\mathrm{B}$ component was not only higher than that in the control group, but also increased with ginkgolide B concentration. However, different concentrations of ginkgolide $B$ had little effect on the differentiation of glial-like cells into oligo4-positive oligodendrocytes $[47,61]$.

Five hours after Salvia (Dan Shen) induction, most rat MSCs expressed NSE, and NF-positive brownish yellow staining, morphological diversity, simple bipolar cells and complex multi-polar cells [62]. GFAP immunohistochemistry was negative. While the control group did not have any nestin positive cells, the majority of cells showed nestin positivity by $5 \mathrm{~h}$ after Salvia induction, indicating that the cells had neural stem cell characteristics. The results of reverse-transcription polymerase chain reaction showed that mash-1 and ngn-1 were not expressed in MSCs before induction, but they were expressed after induction. Salvia induced differentiation of neuron-like cells in addition to the morphological characteristics of neurons at the genetic level $[63,64]$.

There were no cell morphological changes in rat MSCs by $24 \mathrm{~h}$ after injection of Astragalus $(20 \mu \mathrm{L} / \mathrm{mL})$, but visible morphological changes in a small number of cells by $24 \mathrm{~h}$ after injection of Astragalus $(50 \mu \mathrm{L} / \mathrm{mL})$ [65]. Some cell morphology changes were observed in some cells only $5 \mathrm{~h}$ after injection of Astragalus $(100 \mu \mathrm{L} / \mathrm{mL})$. Up to $24 \mathrm{~h}$ after the injection, more neuron-like cells, the formation of slender processes, and network-like connections between the visible parts of cells were observed. Nestin-positive cell staining was strongest $24 \mathrm{~h}$ after injection of Astragalus $(100 \mu \mathrm{L} / \mathrm{mL})$. The numbers of NSE- and GFAP-positive cells were highest $24 \mathrm{~h}$ after injection of Astragalus $(200 \mu \mathrm{L} / \mathrm{mL})$. Only a small number of stained MAP-2-positive cells were observed $24 \mathrm{~h}$ after injection of Astragalus (100 and $200 \mu \mathrm{L} / \mathrm{mL})$. The expression levels of $W n t-1$ and Ngn-1 genes, which play a positive regulatory role in the differentiation process, were significantly higher $[65,66]$. MSCs of rat cultured with serum-free ginseng saponin $\operatorname{Rgl}(10 \mu \mathrm{mol} / \mathrm{L})$ for 3 days, some cells expressed NSE, but GFAP staining was negative [66]. The level of NGF mRNA in the ginsenoside Rgl-treated group was significantly higher than that in the control group, suggesting that ginsenoside $\mathrm{Rgl}$ induced neuron-like cells to express NGF mRNA [67].

\section{Limitations and further studies}

Current research is limited to the effects of a selection of Chinese herbs and their active components on neural stem cell proliferation and differentiation. The mechanisms of their actions are largely unknown. This review is based on animal studies.

\section{Conclusion}

Specific Chinese herbs exhibited effects on the differentiation, proliferation and activation of neural stem cells and mesenchymal stem cells.

\section{Abbreviations \\ CM: Chinese medicine; SVZ: Subependymal zone; SGZ: Subgranular zone; AD: Alzheimer's disease; NSCs: Neural stem cells; DG: Dentate gyrus; MSCs: Mesenchymal stem cells; NSE: Neuron-specific enolase; RRTP: Rose roxburghii tratt polysaccharide; NT-3: Neurotrophin-3; NF: Neurofilament proteins; NGF: Nerve growth factor}

\section{Competing interests}

All authors declare that they have no competing interests.

\section{Authors' contributions}

YS, QL, CX, and XN conducted this review. YS, QL, XX and CY wrote the manuscript. All the authors read and approved the final version of the manuscript.

\section{Acknowledgements}

This paper was sponsored by the National Key Basic Research and Development Program (973 Program) (NO.2011CB505404), the National Natural Science Foundation of China $(81373830,81273631)$ and the Innovation team project of Beijing University of Chinese Medicine (NO.2011-CXTD-05, 2011-CXTD-15)

\section{Author details}

${ }^{1}$ Department of Anatomy, Beijing University of Chinese Medicine, Chaoyang District, Beijing 100029, China. ${ }^{2}$ Department of Phytochemistry, School of Chinese Materia Medica, Beijing University of Chinese Medicine, Chaoyang District, Beijing 100029, China. ${ }^{3}$ Department of Gastroenterology, Dongfang Hospital, Fengtai District, Beijing, China. ${ }^{4}$ Department of Physiology, Beijing University of Chinese Medicine, Chaoyang District, Beijing, China. ${ }^{5}$ Insititute of China Resources Double-crane Pharmaceutical Co., Ltd. Chaoyang District, Beijing, China. ${ }^{6}$ College of Life Science and Technology, Beijing University of Chemical and Technology, Chaoyang District, Beijing 100029 Beijing, China.

Received: 26 March 2013 Accepted: 3 April 2014

Published: 9 April 2014

\section{References}

1. McKay R: Stem cells in the central nervous system. Science 1997, 276(5309):66-71.

2. Reynolds BA, Weiss S: Generation of neurons and astrocytes from isolated cells of the adult mammalian central nervous syetem. Science 1992, 255:1707-1710.

3. Si Y, Cheng $L$, Zhu P, Wu H: The effects of cortical devascularizayion on proliferation of neural stem cell in subependymal ventricular zone of lateral ventricle in rats. Chin J Anat 2007, 30(1):50-53.

4. Einstein $\mathrm{O}$, Ben-Hur T: The changing face of neural stem cell therapy in neurologic diseases. JAMA Neurol 2008, 65(4):452-456.

5. Dietrich J, Kempermann G: Role of endogenous neural stem cells in neurological disease and brain repair. Adv Exp Med Biol 2006, 557:191-220.

6. Erzsebet K, Susan G, Yue W, Steve L, Gang L, Yu S, Badrinath R, Temple QSS: Adult SVZ lineage cells home to and leave the vascular niche via 
differential responses to SDF1/CXCR4 signaling. Cell Stem Cell 2010, 7(2):163-173.

7. Ronaghi M, Erceg S, Moreno-Manzano V, Stojkovic M: Challenges of stem cell therapy for spinal cord injury: human embryonic stem cells, endogenous neural stem cells, or induced pluripotent stem cells? Stem Cells 2010, 28(1):93-99.

8. Lois C, Alvarez-Buylla A: A Long-distance neuronal migration in the adult mammalian brain. Science 1994, 264(5162):1145-8

9. Shi Y, Zhou L, Tian J, Wang Y: Transplantation of neural stem cells overexpressing glia-derived neurotrophic factor promotes facial nerve regeneration. Acta Otolaryngol 2008, 129(8):906-14.

10. Han F: Advances in the study of Chinese medicine treatment of encephalopathy. J Yixuetongxun 1992, 19(5):8-11.

11. Song $X$ : Pharmacological study of single herb and its active ingredient on cerebral ischemia in 2009. Chin J Med Guide 2010, 12(9):1589-1590.

12. Si Y, Cheng L, Zhu P, Wu H: Experimental study on the proliferation of neural stem cells of SVZ in adult rat brain after devascularization. Chin $J$ Anat 2007, 30(1):50-53

13. Si Y, Cheng L, Zhu P: Effects of devascularization on neural stem cells of SGZ in rat brain. Chin J Clin Rehab 2004, v31:35-40.

14. Kornack DR, Rakic P: The generation, migration, and differentiation of olfactory neurons in the adult primate brain. Proc Natl Acad Sci U S A 2001, 98:4752-4757.

15. Cheng Y, Black IB, DiCicco BE: Hippocampal granule neuron production and population size are regulated by levels of bFGF. Eur J Neurosci 2002 15(1):3-12.

16. Gage FH: Mammalian neural stem cells. Science 2000, 287(5457):1433-1438.

17. Zhu P, Cheng L, Si Y, Huang B, Wu H, Xu H: The progenitor cells in the anterior subventricular zone increase proliferation and migration that from migratory pathway to the lesioned site in the adult rat after cortical devascularization (2) Progenitors derived from the dorsolateral subventricular zone from migratory pathway through the corpus callosum to the lesioned site. Chin J Neuroanat 2006, 22(1):21-26.

18. Zhu P, Cheng L, Si Y, Huang B, Wu H, Xu H: The progenitor cells in the anterior subventricular zone increase proliferation and migration that from migratory pathway to the lesioned site in the adult rat after cortical devascularization (1) the site of proliferation and migratory of progenitors locates in the dorsolateral subventricular zone. Chin $\rfloor$ Neuroanat 2005, 21(6):583-59.

19. Cui R, Pu C, Liu J: Effects of ginsenoside Rg1 on the proliferation of neural stem cells in rats with focal cerebral ischemia. Med J Chin People's Liberation Army 2007, 32(8):842-845.

20. Compiled by National Pharmacopoeia Commission: Pharmacopoeia of People's Republic of China(1). Chinese medical Science and Technology Press. 2010, (1):174-175.

21. Jiang $Q$, Shi Y: Research of Ginsengnoside Rg1 on enhancing protection of SVZa-NSCs of rats and expression of STAT3. Chin J Basic Med Traditional Chin Med 2009, 15(10):748-753.

22. Compiled by National Pharmacopoeia Commission: Pharmacopoeia of People's Republic of China(1). Chinese medical Science and Technology Press. 2010, (1):192-193.

23. Lin $H$, Wang $Y$, Xing $Y$, Yang $L$, Hu H: Effects of Acanthopanax Senticosus Injection on the Cerebral Ischemia in Rats. J Sichuan Univ (Natural Sci Ed) 2006, 43(1):217-221.

24. Compiled by National Pharmacopoeia Commission: Pharmacopoeia of People's Republic of China(1). Chinese medical Science and Technology Press. 2010, (1):124-125.

25. Yu H, Liu D, Wu Y, Cheng J, Yang X: Effect of angelica on proliferation of neural stem cells from rats' embryos in hypoxia model. Chin J Modern Med 2005, 15(21):3226-3228.

26. Compiled by National Pharmacopoeia Commission: Pharmacopoeia of People's Republic of China(1). Chinese medical Science and Technology Press. 2010, (1):144.

27. Qin Y, Zeng Y, Zhou C, Li Y, Zhong Z: Effects of Rhodiola roseaon level of5-hydroxytryptam ine, cell proliferation and differentiation, and number of neuron in cerebral hippocampus of rats with depression induced by chronic mild stress. Chin J Chinese Materia Med 2008, 33(23):2842-2846.

28. Ding $Y$, Zeng $Y$, Ma Q: Effect of ganoderma spores on neural stem cells in injured spinal cord of rat. Chin J Integr Med 2004, 24:65-68.
29. Compiled by National Pharmacopoeia Commission: Pharmacopoeia of People's Republic of China(1). Chinese medical Science and Technology Press. 2010, (1):146-147.

30. Hi J, Gao Z, Ke K: Effects of total saponins of panax ginseng on the proliferation of endogenous neural stem cells following intracerebral hemorrhage. Acta Acad Med Nantong 2009, 29(4):253-255.

31. Wen J, Yang B, Xue C, Ren D: The study of polygala tenuifolia willd promote neurogenesis in Alzheimer's diseasemodel mice. Chin J Neuroanat 2010, 26(2):145-149.

32. Qi C, Liu Y, Tian Y, Zhang J, Chen X, Zhang P, Qiu F, Xiao X, Zhang J: Effects of tetramethylpyrazine on cell proliferation in dentate gyrus in rat brain after cerebral ischemia-reperfusion injury. I Xi'an Jiaotong Univ (Med Sci) 2007, 28(2):1671-1675

33. Hao W, Yang N, Gao Y, Hao Q, Zhang G, Zhu H, Zuo P: Effect of the crude extract of cape jasmineon behavior and the hippocampal neurogenesis in mouse model of depression. Chin J Comparative Med 2009, 19(10):11-13.

34. Zhang W, Li Y, Zhong Z, Wang S, Chen L: Effect of Salidroside on neural stem cell. Heilongjiang Med Pharmacy 2005, 28(6):3-4.

35. Wang C, Zhang Y, Feng Y, Zhuang P, Wang J, Liu H, Wang L: Effect of astragaloside IV on neurogenesis in adult hippocampus of ratsafter transient forebrain ischemia. Chin Traditional and Herbal Drugs 2009, 40(5):754-758

36. Cui R, Pu C, Liu J: Effects of ginsenoside Rg1 on the expression of nestin in rats brain with focal cerebral ischemia. Stroke Nervous Dis 2007, 14(1):44-46.

37. Si Y, Li X, Li H: Effects of injection of TONGLUOJIUNAO on the positive cells of Vimentin and GFAP in SVZ in rat brain. Chin J Traditional Chin Med 2009, 24(6):709-712.

38. Si $Y, L i J$, Zhang L: Effects of panax notoginseng saponins on proliferation and differentiation of neural stem cells in SVZ in rat brain after cerebral hemorrhage. J Clin Rehab Tissue Eng Res 2008, 12(8):1414-1417.

39. Si Y, Cheng L, Hong Q, Tang Y, Zhu P: Experimental study on proliferation and differentiation of neural stem cells of rat embryo in vivo by panax notoginseng saponins. Chin J Stereology Image Anal 2004, 9(2):78-83.

40. Zhang J: Nootropic mechanisms of ginsenoside Rg1 influence on neuronal plasticity and neurogenesis. Acta Pharm Sin 2005, 40(5):385-388.

41. Compiled by National Pharmacopoeia Commission: Pharmacopoeia of People's Republic of China(1). Chinese medical Science and Technology Press. 2010, (1):283-284.

42. Liu J, Yao Z, Qin M, Chen X, Jian-fang C: Effect of simple astragali,flos cartham i,salviam iltiorrhiza injection on differentia-tion of neural stem cells. Acta Acad Med Militaris Tertiae 2006, 28(14):1470-1472.

43. Compiled by National Pharmacopoeia Commission: Pharmacopoeia of People's Republic of China(1). Chinese medical Science and Technology Press. 2010, (1):361-362.

44. Shen Z, Huang J, Wu B: Activating effect and mechanism of epmiedium on endogenous stem cells. Chin J Integrated Traditional and Western Med 2009, 29(3):251-254.

45. Zhuang $P$, Zhang $Y$, Pang $T$ : Effects of brain microvascular endothelial cells and astrocytes following treatment with baicalin on neural stem cell differentiation. J Clin Rehab Tissue Eng Res 2009, 13(7):43-47.

46. Ding $Y$, Zeng $Y$, Zhang W, Chen S: The effects of ginkgolid B of various consistency on the differentiation of neural stem cells. Acta Anatomica Sinica 2004, 35(5):486-488,

47. Wang Y, Luo X, Shi Y: Mechanisms and effect of ginkgolide $B$ on the differentiation of neuron stem cells. Chin J Rehab Theory Practice 2007, 13(8):701-703

48. Yang J, Chen F, Liang G: The protective effect of polysaccharides from roxburghii tratt on neural stem cells damaged by glutamic acid. Acta Nutrimenta Sinica 2005, 27(4):339-341.

49. Zhang L, Li Y, Liu Y, Yang M, Zhao Y, Gong Z: Effect of [quercetin 3-Oapiosy $1(1 \rightarrow 2)$-rhamnosy $1(1 \rightarrow 6)$-glucoside on the proliferation of neural progenitor cells from neonatal rat hippocampus. Chin Pharmacol Bull 2006, 22(2):171-174.

50. Chen D, Meng X, Liu J, Chen L, Lu L: Effect of velvet antler polypeptide (VAP) on differentiation of rat brain-derived stem cells in vitro. Acta Anatomica Sin 2004, 35(3):240-243.

51. Zhuang $P$, Zhang $Y$, Pang T: Proliferation effect of neural stem cell of Ginsenoside Rg1 in vitro. C Materia Med 2009, 34(4):443-448.

52. Shi Y, Luo X, Wang Y, Liu H, Yao Z: Protective effect of panaxoside Rg1 and $\mathrm{Rbl}$ on cultured neural stem cells from anterior subventricular zone 
of the rat against glutamin exitotoxicity and its relation with the expression of stat3. Int J Cerebrovascular Dis 2007, 15(3):172-176.

53. Wang $S, L i Y$, Wang $Y$, Feng M: Effect of TSPG on proliferation and differentiation of human embryonic neural stem cell into dopaminergic neuron. Chin J Chin Materia Medica 2007, 32(13):1310-1313.

54. Wang $S$, Li Y, Wang Y: Effect of total saponin of panax ginseng on mice with Parkinson disease treated by neural stem cell transplantation. Chin J Clin Rehab 2006, 10(41):19-21.

55. Liu J, Luo X, Zhong S, Liu H, Yao Z: Effects of Saponins of Astragalus on differentiation of neural stem cells. J Fourth Military Med Univ 2009, 30(7):580-583.

56. Zhang $M, L i Y$, Du R: Effect of baicalin on differentiation of neural stem cells in vitro. J Tianiin Univ Traditional Chin Med 2007, 26(4):199-201.

57. Chao $H$, Zhu X: Protective effect of tanshinone on rat neural stem cell damage. Heilongjiang Med Pharmacy 2002, 25(5):6-7.

58. Chen Z, Yang H, Yang H: High dose of methylprednisolone (MP) on acute spinal cord injury (ASCl). Chin J Spine Spinal Cord 2006, 16(7):33-35.

59. Zhang W, LV J, Bai D, Li S, Feng K, Xu Y: Ginkgo biloba leaf extract combined with transplantation of nerve stem cells transfected with neurotrophin-3 in treating acute spinal cord injury. Chin J Orthopaedic Trauma 2010, 18(5):16-18.

60. Su P, Huang J, Luo X, Huang P, Huang Y, Pei X: Effects of differentiaton of mesenchymal stem cells into neuron-like cells with ginkgolide $B$. Guangdong J Med 2007, 28(1):33-35.

61. Huang $Z$, Jin $G$, Zhang X, Tian E, Qin J, Xu H: The inducing effects of ginkgolide $B$ on neural stem cells differentiating into neurons. Acta Anatomica Sinica 2003, 34(4):367-371.

62. Compiled by National Pharmacopoeia Commission: Pharmacopoeia of People's Republic of China(1). Chinese medical Science and Technology Press. 2010, (1):70-71.

63. Xiang P, Xia W, Wang L, Chen Z, Zhang L, Zhang X, Li Y, Li S: Differentiaton of human mesenchymal stem cells into neuron-like cells with danshen injection. Acad J SUMS 2001, 22(5):321-324.

64. Wang Y, Lu C, Wang F: Differentistion of rat bone marrow Stem cells into neuron-like cells induced by salvia mtiorrhiza. Chin J Anat 2007, 2(30):207-210.

65. Dong L, Wang Y, Lu C, Wang F: Effect of astragalus mongholicuson inducing differentiations of rat bone marrow-derived mesenchymal stem cells into neurocyte-like cells. Sichuan Da Xue Xue Bao Yi Xue Ban 2007, 38(3):417-420.

66. Wang $X$, Cui $H, M a H$, Sun $L, B \circ A$ : Differentiation of rat bone marrow mesenchymal stem cells induced by astragalus monbholieus. Chin J Anat 2007, 30(5):534-537.

67. Wu W, Yan J, Zhang Y: The effect of ginsenoside Rgl on differeotiation of bone marrow mesenchymal stem cells into neuron-like cells. J Apoplexy Nerv Dis 2007, 24(3):282-284.

doi:10.1186/1749-8546-9-13

Cite this article as: $\mathrm{Si}$ et al.: Chinese herbs and their active ingredients for activating xue (blood) promote the proliferation and differentiation of neural stem cells and mesenchymal stem cells. Chinese Medicine 2014 9:13.

\section{Submit your next manuscript to BioMed Central and take full advantage of:}

- Convenient online submission

- Thorough peer review

- No space constraints or color figure charges

- Immediate publication on acceptance

- Inclusion in PubMed, CAS, Scopus and Google Scholar

- Research which is freely available for redistribution 